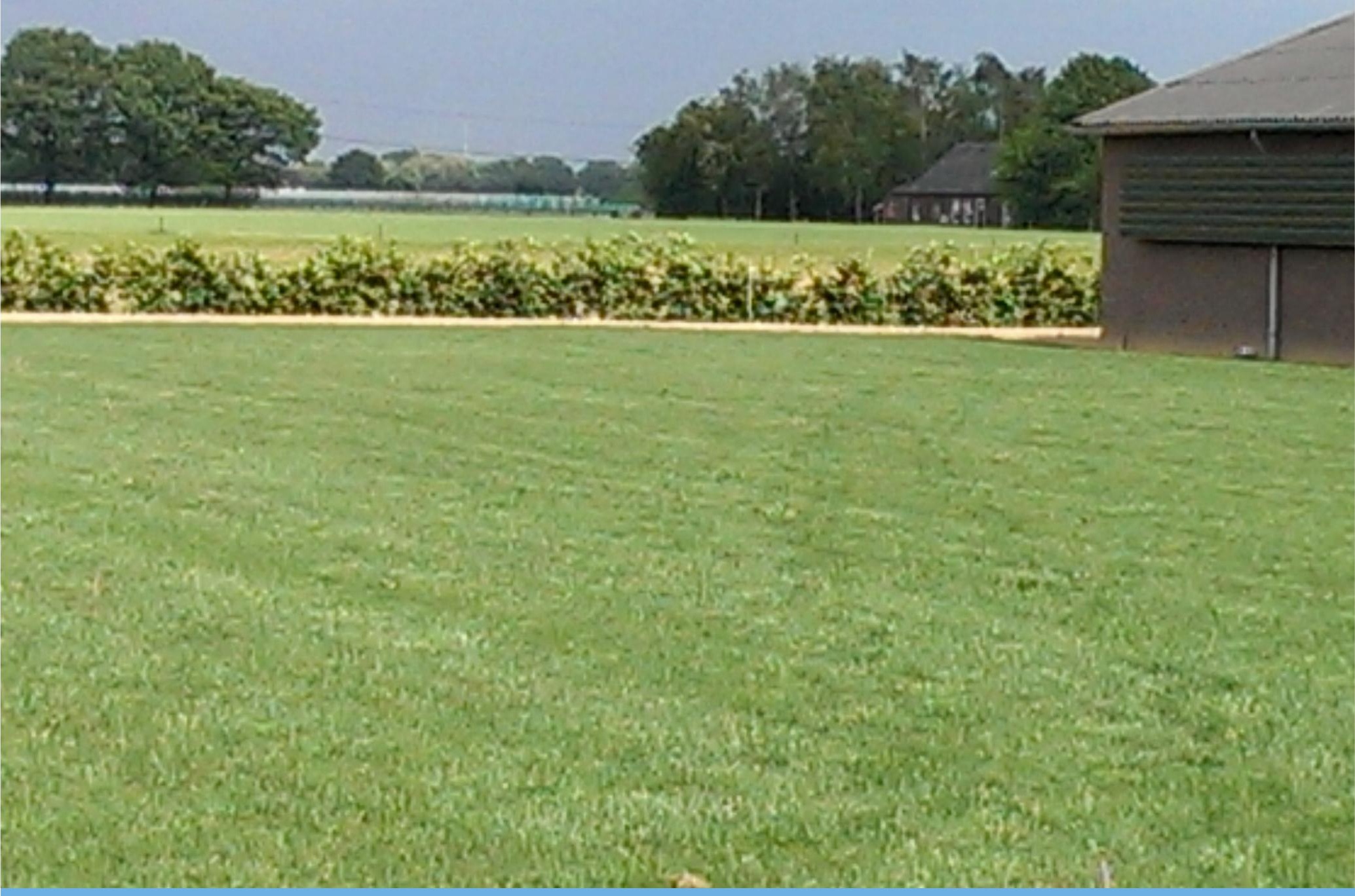

\title{
Actualisering geuremissiefactor vleeskuikens
}




\section{Actualisering geuremissiefactor vleeskuikens}

N.W.M. Ogink, H. Ellen, J. Mosquera 
Ogink, N.W.M., H. Ellen, J. Mosquera, 2016. Actualisering geuremissiefactor vleeskuikens; . Wageningen Livestock Research, Livestock Research Rapport 960.

Samenvatting: Het doel van deze studie was een advies uit te brengen voor de actualisering van de geuremissiefactor voor vleeskuikenstallen in de Regeling geurhinder en veehouderij (Rgv). De actualisering is gebaseerd op een statistische analyse van geuremissiedata uit studies uitgevoerd in 28 vleeskuikenstallen tussen 1996 en 2014. De hoofdconclusie van deze analyse is dat een voor de huidige praktijk representatieve geuremissiefactor hoger is dan de momenteel in gebruik zijnde Rgvfactor. De huidige geuremissiefactor bedraagt voor vleeskuikenstallen zonder nageschakelde technieken $0.24 \mathrm{OU}_{\mathrm{E}} / \mathrm{s}$ per geplaatst dier. Geadviseerd wordt deze factor bij te stellen naar $0.33 \mathrm{OU}_{\mathrm{E}} / \mathrm{s}$ per geplaatst dier.

Summerijy: The aim of this study was to advice on the update of the odour emission factor for broiler houses that is used in the national regulation to control nuisance from odour from livestock (Rgv) in the Netherlands. The update was based a statistical analysis of odour emission data from field studies carried on 28 broiler barns between 1996 en 2014. The main conclusion drawn from this analysis was that the odour emission under current management conditions is higher than the so far used odour emission factor in the Rgv-regulation. The current odour emission factor in the Rgv assigned to broiler houses without additional air cleaning techniques amounts $0.24 \mathrm{OU}_{\mathrm{E}} / \mathrm{s}$ per placed bird. It is advised to adjust this factor to $0.33 \mathrm{OU}_{\mathrm{E}} / \mathrm{s}$ per placed bird.

Dit rapport is gratis te downloaden op http://dx.doi.org/10.18174/391901 of op www.wur.nl/livestock-research (onder Wageningen Livestock Research publicaties).

\section{(C) 2016 Wageningen Livestock Research}

Postbus 338, 6700 AH Wageningen, T 03174839 53, E info.livestockresearch@wur.nl, www.wur. nl/livestock-research. Wageningen Livestock Research is onderdeel van Wageningen University \& Research.

Wageningen Livestock Research aanvaardt geen aansprakelijkheid voor eventuele schade voortvloeiend uit het gebruik van de resultaten van dit onderzoek of de toepassing van de adviezen.

Alle rechten voorbehouden. Niets uit deze uitgave mag worden vermenigvuldigd en/of openbaar gemaakt worden door middel van druk, fotokopie, microfilm of op welke wijze dan ook zonder voorafgaande toestemming van de uitgever of auteur.

De certificering volgens ISO 9001 door DNV onderstreept ons kwaliteitsniveau. Op als onze onderzoeksopdrachten zijn de Algemene Voorwaarden van de Animal Sciences Group van toepassing. Deze zijn gedeponeerd bij de Arrondissementsrechtbank Zwolle. 


\section{Inhoud}

$\begin{array}{ll}\text { Woord vooraf } & 5\end{array}$

$\begin{array}{ll}\text { Samenvatting } & 7\end{array}$

$\begin{array}{ll}\text { Summary } & 9\end{array}$

$\begin{array}{llr}1 & \text { Inleiding } & 11\end{array}$

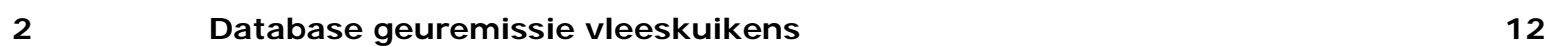

2.1 Beschikbare data $\quad 12$

$\begin{array}{lll}2.2 & \text { Statistische analyse en berekeningen } & 13\end{array}$

3

$\begin{array}{ll}\text { Resultaten } & 16\end{array}$

3.1 Statistische analyse variabiliteit geuremissie $\quad 16$

$\begin{array}{lll}3.2 & \text { Berekening geuremissiefactor } & 17\end{array}$

$\begin{array}{lll}3.3 & \text { Geuremissiecurve voor verspreidingsberekeningen } & 18\end{array}$

4

$\begin{array}{ll}\text { Discussie en conclusies } & 20\end{array}$

$\begin{array}{ll}\text { Literatuur } & 23\end{array}$

$\begin{array}{lll}\text { Bijlage } 1 & \text { Overzicht metingen } & 24\end{array}$

$\begin{array}{lll}\text { Bijlage } 2 \text { Vergelijkende geurmetingen } & 25\end{array}$ 



\section{Woord vooraf}

De Regeling geurhinder en veehouderij (Rgv) bevat geuremissiefactoren die per diercategorie zijn vastgesteld op basis van meetgegevens. Deze gestandaardiseerde geuremissiefactoren worden in de Rgv gebruikt voor het berekenen van de te verwachten geurbelasting rond stallen. Als gevolg van veranderingen in stalinrichting en voer- en stalmanagement kunnen geuremissies in de loop der tijd veranderen. Er zijn aanwijzingen dat de huidige geuremissiefactor voor vleeskuikenstallen niet voldoet, mogelijk als gevolg van veranderingen in de vleeskuikensector. De geuremissiefactor voor vleeskuikens is voor het laatst in 2005 vastgesteld. $\mathrm{Er}$ is daarom behoefte aan een actualisering van de geuremissiefactor voor vleeskuikenstallen. Na 2005 zijn nieuwe meetseries uitgevoerd in vleeskuikenstallen die voor dit doel gebruikt kunnen worden. Dit rapport brengt een advies uit over de actualisering van de geuremissiefactor voor vleeskuikenstallen op basis van een analyse van alle beschikbare meetgegevens. Deze studie is uitgevoerd in opdracht van het ministerie van Infrastructuur en Milieu.

Nico Ogink

Projectleider

Wageningen Livestock Research 


\section{Samenvatting}

De Regeling geurhinder en veehouderij (Rgv) bevat geuremissiefactoren die per diercategorie zijn vastgesteld op basis van meetgegevens of zijn afgeleid van meetgegevens. Als gevolg van veranderingen in stalinrichting en voer- en stalmanagement kunnen geuremissies in de loop van de tijd veranderen. De in 2015 geformeerde bestuurlijke werkgroep Geur van het ministerie van I\&M heeft in een tussentijdsadvies aan de staatssecretaris van I\&M vastgesteld dat er behoefte is aan het herijken van geuremissiefactoren, reductiepercentages en berekeningsmethoden van bepaalde diercategorieën. De bestuurlijke werkgroep gaf aan dat er een groot verschil lijkt te bestaan tussen de berekende en ervaren geurbelasting, met name bij vleeskuikens. De werkgroep vroeg daarom om een herijking en actualisatie van de geurfactor voor vleeskuikenstallen uit te voeren. De geuremissiefactor voor vleeskuikens (categorie E5 in de Rav) is voor het laatst in 2005 vastgesteld met toen beschikbare emissiegegevens. De huidige geuremissiefactor voor vleeskuikens bedraagt $0.24 \mathrm{OU}_{\mathrm{E}} / \mathrm{s}$ per geplaatst dier. Het merendeel van de subcategorieën in E5 is dit basisniveau toegekend. De overige E5categorieën met luchtzuiveringssystemen of alternatief management zijn van dit basisniveau afgeleid.

Het doel van deze studie is een advies uit te brengen over de actualisering van de geuremissiefactor voor vleeskuikens (Rav code E5) met gebruikmaking van alle beschikbare meetdata die representatief zijn voor de Nederlandse praktijk. De actualisering is gericht op de geuremissiefactor van het basisniveau. In het advies wordt tevens aandacht besteed aan de wijze waarop de beschikbare geuremissie informatie het best kan worden toegepast in het huidige rekenmodel V-Stacks vergunning 2014.

Voor de actualisering is een statistische analyse uitgevoerd van beschikbare meetgegevens tussen 1996 en 2014. Hiervoor zijn de gegevens van 28 stallocaties in een database opgenomen, in totaal 197 geuremissiemetingen uit zowel conventionele stallen (E5.100) als ammoniakemissie-arme stallen zonder nageschakelde techniek. Alle metingen zijn volgens toen geldende meetprotocollen voor geuremissie uitgevoerd. De statistische analyse was gericht op beschrijving van een geuremissiecurve als functie van het aantal dagen in een productieronde en emissiebepalende factoren en variabelen. In de analyse is gekeken naar de effecten op geuremissie van groei (uitgedrukt als dagnummer in de ronde), ventilatiedebiet, temperatuur, ammoniakemissie-arm stalsysteem, uitvoerend geurlaboratorium en mogelijke wijziging in geuremissiebepalende factoren die aan tijdvakken verbonden zijn.

Uit de statistische analyse volgde dat de geuremissie het best beschreven kan worden als functie van dagnummer in de ronde en ventilatiedebiet. Beide variabelen zijn verbonden met de toename in diergewicht, voeropname en mestproductie gedurende een productieronde. De analyse leverde geen aanwijzing voor effecten van ammoniakemissie-arm stalsysteem of verschillen tussen uitvoerend geurlaboratorium op de gemeten geuremissie. In de statistische analyse is vooraf op basis van verandering in omgevingsfactoren met mogelijk effect op de geuremissie een tijdvak effect gedefinieerd. Het gaat hier met name om wijzigingen die kunnen zijn geassocieerd met veranderingen in voersamenstelling. Met deze tijdvakfactor kon het verschil in geuremissieniveau tussen data uit onderzoek tot 2001 en onderzoek vanaf 2001 worden geanalyseerd. Uit de analyse komt een groot verschil tussen beide tijdvakken naar voren met een gemiddeld meer dan de helft hogere geuremissie na 2001. Gezien de omvangrijkheid van het effect en het gegeven dat de meer recentere reeksen vanaf 2001 zijn verkregen van bedrijven die qua management en uitvoering dichter bij de huidige vleeskuikenbedrijven staan, is het advies deze verhoging in de geactualiseerde geuremissiefactor op te nemen.

Met behulp van het best beschrijvende statistische model is het verloop van de geuremissie gedurende een gemiddeld meteorologisch jaar berekend. Het verloop laat een karakteristiek zaagtandpatroon dat synchroon loopt met de opzet van de rondes. De maximale geuremissies aan het eind van de rondes fluctueren door het jaar met hogere geuremissie-pieken in de zomerperiode. De seizoensvariatie is 
echter veel geringer dan de variatie binnen een ronde. Het opnemen van deze emissiepatronen in verspreidingsberekeningen geeft een meer realistisch beeld bij de inschatting van de 98-

percentielwaarden in de geurbelaste omgeving dan berekeningen gebaseerd op een constante bronsterkte zoals nu wordt toegepast in het V-Stacks model.

Uit de statistische beschrijving van de geuremissiecurve is vervolgens de geuremissiefactor berekend als het gemiddelde in een productieronde, gemodelleerd op het geuremissieniveau vanaf 2001. Het gemiddelde niveau is berekend bij een zo representatief mogelijk gemiddeld ventilatiedebiet. Dit debiet is mede afhankelijk van de buitentemperatuur. Omdat de gemiddelde buitentemperatuur in de database iets hoger lag dan het tienjaargemiddelde van de buitentemperatuur is het in de berekening gebruikte ventilatiedebiet gecorrigeerd naar dit tienjaargemiddelde.

Uit de analyse blijkt dat de huidige geuremissiefactor factor in de Rgv (0.24 $\mathrm{OU}_{\mathrm{E}} / \mathrm{s}$ per geplaatst dier) dient te worden geactualiseerd naar een hoger niveau. Geadviseerd wordt de actualisering te baseren op het best beschrijvende statistische model, het niveau af te stemmen op tijdvak vanaf 2001 en de voorgestelde correctie naar een representatief ventilatiedebiet. De geactualiseerde geuremissiefactor bedraagt dan $0.33 \mathrm{OU}_{\mathrm{E}} / \mathrm{s}$ per geplaatst dier. Geadviseerd wordt bij de berekeningen met het $\mathrm{V}$ Stacksmodel rekening te houden met het zaagtandpatroon in geuremissie. 


\section{Summary}

Broiler production in the Netherlands is typically based on all-in all-out systems with production cycles of 5-7 weeks, characterized by a stepwise increase of odour emission during the cycle. Odour nuisance around broiler farms is known to be especially related to the last 2 production weeks. Increasing numbers of nuisance complaints have been reported over the last years, suggesting increasing odour emission from broiler barns. The objective of this study was to evaluate the evolution of odour emissions in broiler production throughout the last two decades, provide an updated odour emission factor for broiler housing to be used in odour regulations, and to provide information on the odour emission as function of the production cycle.

A database was created with measurements from different research programmes: 28 broiler farms, taken between 1996 and 2014, with two standardized measurement protocols, including 197 measurements on odour concentration (sampled between 10-12 am), ventilation rate, day in production cycle, inside and outside temperature, bird type and odour lab. The analysis included effects associated with the change in feed composition (ban on antibiotic feed additives from 2001 on), change in executing odour laboratory from 2010 on, and the effect of housing systems (conventional versus low ammonia emission housing) on odour emission (In-scale).

Results showed no effects of housing system and odour lab ( $P>0.10)$, whereas changes in feed composition after 2001 was associated with an increase in odour emission $(P<0.08)$. This effect was confounded with a change in the type of olfactometer within the first odour lab in 2001. Predicted means before and after 2001, amounted 0.22 and $0.33 \mathrm{OU}_{\mathrm{E}} / \mathrm{s}$ per bird, the latter being substantially higher than the current emission factor of 0.24 .

It is concluded that odour emissions from housing systems with ammonia mitigation measures do not differ from conventional broiler barns and that no systematic differences were found between the two odour laboratories involved. The current odour emission needs revision. Based on the results of the statistical analysis it is advised to use the estimated odour emission from measurements after 2001 for this purpose, increasing the odour emission factor for broiler housings from 0.24 to $0.33 \mathrm{OU}_{\mathrm{E}} / \mathrm{s}$ per bird. Furthermore it is recommended in case of farm licensing procedures to incorporate production cycle dependent fluctuation in odour emission in odour dispersion modelling. 


\section{$1 \quad$ Inleiding}

De Regeling geurhinder en veehouderij (Rgv) bevat geuremissiefactoren die per diercategorie zijn vastgesteld op basis van meetgegevens. Als gevolg van veranderingen in stalinrichting en voer- en stalmanagement kunnen geuremissies in de tijd veranderen. De in 2015 geformeerde bestuurlijke werkgroep Geur van het ministerie van I\&M heeft in een tussentijds advies aan de staatssecretaris van I\&M vastgesteld dat er behoefte is aan het herijken van geuremissiefactoren, reductiepercentages en berekeningsmethoden van bepaalde diercategorieën. De bestuurlijke werkgroep geeft aan dat er een groot verschil lijkt te bestaan tussen de berekende en ervaren geurbelasting, met name bij vleeskuikens. De werkgroep vraagt daarom om een herijking en actualisatie van de geurfactor voor vleeskuikenstallen uit te voeren. Overlast uit vleeskuikenstallen wordt met name gemeld in de laatste weken van de mestperiode ( $5 \mathrm{de}$, $6 \mathrm{de}$ en $7 \mathrm{de}$ week). In een recent onderzoek naar dosis-effect relaties bij geurhinder rond stallen (Geelen et al., 2015) wordt aanbevolen rekening te houden met de tijdsprofielen van geuremissies. Door het in de vleeskuikensector toegepaste 'all in - all out' systeem met synchrone productierondes in de aanwezige stallen nemen de bedrijfsemissies sterk toe gedurende de ronde. In de betreffende studie wordt gesteld dat het ondanks onduidelijkheid over de exacte effecten van fluctuerende uitstoot aannemelijk is dat deze fluctuaties de uitstoot het optreden van hinder kunnen beïnvloeden.

Het is van belang dat deze actualisering op korte termijn wordt ingezet met het oog op de inbouw van de Wet geurhinder en veehouderij (Wgv) in de Omgevingswet, zodat een geuremissiefactor wordt vastgesteld die recht doet aan de ondervonden geurbelasting, op een wijze die is uit te voeren binnen de huidige wet- en regelgeving.

De geuremissiefactor voor vleeskuikens is voor het laatst in 2005 vastgesteld met toen beschikbare emissiegegevens volgens een methode die is gedocumenteerd in het Livestock Research rapport 391 (Ogink, 2010). De huidige geuremissiefactor voor vleeskuikens in de Regeling geurhinder en veehouderij (Rgv) bedraagt $0.24 \mathrm{OU}_{\mathrm{E}} / \mathrm{s}$ per geplaatst dier voor de Rav-categorieën E5.1, 5.2, 5.3, 5.5, $5.6,5.8,5.10,5.11,5.14$ en 5.100, hierna verder aangeduid als het basisniveau. Door de aanwezigheid van luchtzuiveringssystemen heeft een aantal E5 categorieën lagere geuremissies. Deze zijn afgeleid van het basisniveau met gebruikmaking van een aan de luchtzuivering toegekend geurverwijderingsrendement (E5.4, 5.7, 5.12 en 5.13). Daarnaast is aan categorie E5.9 met een alternatief houderijsysteem een afwijkende geuremissie toegekend, eveneens middels een afleiding van het basisniveau.

Het doel van deze studie is een advies uit te brengen over de actualisering van de geuremissiefactor voor vleeskuikens (Rav code E5) met gebruikmaking van alle beschikbare meetdata die representatief zijn voor de Nederlandse praktijk.

De actualisering is gericht op de geuremissiefactor van het basisniveau (E5.1, 5.2, 5.3, 5.5, 5.6, 5.8, $5.10,5.11,5.14$ en 5.100). De overige E5 categorieën kunnen hier vervolgens van worden afgeleid. In het advies wordt tevens aandacht besteed aan de wijze waarop de beschikbare geuremissie informatie het best kan worden toegepast in het huidige rekenmodel V-Stacks vergunning 2014.

In hoofdstuk 2 wordt de voor deze studie samengestelde database met geuremissiemetingen in vleeskuikenstallen beschreven. Na 2005 zijn nieuwe meetseries uitgevoerd in vleeskuikenstallen die tezamen met eerdere meetgegevens in deze database zijn opgenomen. De gegevens in de database worden geanalyseerd met statistische modellen, met als doel het ontwikkelen van een geuremissiecurve als functie van het aantal dagen in een productieronde en emissiebepalende factoren. Uit deze geuremissiecurve kan de geuremissiefactor worden berekend. In hoofdstuk 3 worden de resultaten van deze analyse weergegeven, waarna in hoofdstuk 4 de resultaten worden bediscussieerd, gevolgd door conclusies en advies voor gebruik in de Rgv. 


\section{Database geuremissie vleeskuikens}

\section{$2.1 \quad$ Beschikbare data}

De database is opgebouwd uit de afzonderlijke meetdata van alle in Nederland gepubliceerde geuremissie-onderzoeken in vleeskuikenstallen die uitgevoerd zijn in de periode 1996-2014. Het merendeel van de metingen is onderdeel van twee grote onderzoeksprogramma's naar emissie uit de veehouderij. In de periode 1996-2001 zijn geurmetingen uitgevoerd in de belangrijkste diercategorieën voor het vaststellen van geuremissiefactoren voor de geurhinderregelgeving. In het onderzoeksprogramma naar fijnstofemissie uit stallen en het effect van stofreducerende maatregelen (2007 -2012) zijn in veel gevallen tevens geurmetingen uitgevoerd. Daarnaast zijn er enige meetseries beschikbaar uit onderzoek naar ammoniakreducerende maatregelen waarbij geuremissie eveneens is bemeten, zoals bijv. uitgevoerd binnen het MIDS-programma (2011-2013) en het PASonderzoeksprogramma (2013-2014).

In de metingen is gebruikt gemaakt van de meetprotocollen die ten tijde van de uitvoering golden, dat wil zeggen de protocollen die door de Nederlandse overheid werden geadviseerd of voorgeschreven ten behoeve van het vaststellen van geuremissies uit de veehouderij. In de meetseries tot en met 2007 is gebruikt gemaakt van het meetprotocol voor geuremissie beschreven door Mol en Ogink (2002). In dit protocol zijn bedrijfsmetingen van vleeskuikenstallen gebaseerd op het doormeten van 2 productierondes waarvan 1 ronde tussen 1 juni en 1 september diende te liggen, en de ander tussen 1 oktober en 1 januari. In elke ronde vinden 5 metingen plaats gelijkelijk verdeeld over de totale lengte van de ronde, totaal dus 10 metingen per bedrijfslocatie. De geuremissiefactor wordt hieruit berekend als het geometrisch gemiddelde van de gemeten geuremissies (gebaseerd op het gemiddelde van de meetwaarden uitgedrukt op natuurlijke logschaal, welk gemiddelde vervolgens weer is omgezet naar normale schaal via de exponentiële functie). Hoewel volgens het toenmalige protocol 1 bedrijfslocatie volstond voor het vaststellen van een geuremissiefactor kon in 2005 bij het vaststellen van een geuremissie voor vleeskuikenstallen gebruik gemaakt worden van de datasets van 12 afzonderlijke bedrijfslocaties die elk volgens deze meetstrategie waren uitgevoerd.

Vanaf 2007 is een andere meetstrategie toegepast voor het vaststellen van emissiefactoren van bedrijfssystemen, waarbij standaard minimaal 4 bedrijfslocaties dienen te worden doorgemeten voor een emissiefactor, dit om de spreiding tussen bedrijven uit te middelen (Ogink, 2011). Per bedrijfslocatie dienen daarbij 6 metingen, 1 meting per tweemaandelijkse periode te worden uitgevoerd, waarbij voor vleeskuikenstallen de metingen over drie opeenvolgende tijdvakken in de productieronde worden verdeeld: 1 meting in het eerste tijdvak, 2 in het tweede, en 3 in het derde tijdvak. Deze wijziging in meetstrategie per bedrijf is gebaseerd op de waarneming dat, als gevolg van de grotere variabiliteit van de geuremissie aan het eind van de ronde, de nauwkeurigheid van het gemiddelde emissieniveau door meer waarnemingen in het laatste tijdvak van de ronde wordt verbeterd. De geuremissie wordt bij deze benadering berekend als het overall gemiddelde van de drie tijdvak-gemiddeldes (allen op basis van natuurlijke logaritmes van de meetgegevens berekend, waarbij het overall gemiddelde uiteindelijk weer op normale schaal is uitgedrukt).

In zowel het oude als huidige meetprotocol wordt voorgeschreven de bemonstering uit te voeren tussen 10.00 en 12.00 uur, en het ventilatiedebiet gedurende deze periode te meten. De geurmonsters dienden tot 2004 te worden geanalyseerd volgens de NVN2820/A1 uit 1996 en na 2004 volgens de NEN-EN 13725 (NEN, 2003). Doordat de werkwijze in de Nederlandse voornorm zodanig aansluit op de Europese norm dat beide normen een gelijkwaardige geureenheid leveren, is er geen omrekening van eenheden nodig om data uit beide tijdvakken in de database vergelijkbaar te maken. Alle geurconcentratie-metingen zijn uitgevoerd door, voor de genoemde normen, geaccrediteerde laboratoria. In alle concentratie-metingen is gebruik gemaakt van de zogenoemde 'forced choice' methode beschreven in de NEN-EN 13725. De ventilatiedebieten zijn in een deel van de stallen bepaald met meetwaaiers en voor de overige stallen bepaald met gebruikmaking van de $\mathrm{CO}_{2}$ - 
massabalans methode. De geuremissie wordt uitgedrukt als $\mathrm{OU}_{E} / \mathrm{s}$ per geplaatst dier, d.w.z. dat de totale geuremissie t.o.v. het aantal geplaatste dieren bij de aanvang van de productieronde wordt uitgedrukt.

In Tabel 1 wordt een overzicht gegeven van het aantal locaties en metingen, en hun verdeling over stalsystemen. In bijlage 1 is een overzicht opgenomen van de basiskenmerken van de bemeten stallen in de database en de bijbehorende meetrapporten. In totaal bevat de database 197

geuremissiemetingen. In de database zijn alle factoren meegenomen die mogelijk van invloed zijn geweest op de geuremissie en waarvoor voldoende informatie over de gehele meetreeks (1996-2014) beschikbaar was:

1. Staltechnische informatie: stallocatie, huisvestingssysteem, ventilatiesysteem.

2. Diertechnische informatie: aantal dieren bij start ronde en tijdens meting, dag in productieronde, merk vleeskuiken (deels bekend).

3. Klimaatgegevens: datum meting, buiten en binnentemperatuur (deels bekend), buiten en binnen RV (deels bekend), ventilatiedebiet.

4. Tijdvak factoren: twee tijdvak-effecten zijn onderzocht, 1) het effect van geurlaboratorium en 2) een gecombineerd effect van voersamenstelling en olfactometer-type op de geuremissiemetingen voor en na 2001. Het geurlaboratorium-effect (aangeduid als F-geurlab) heeft betrekking op het gebruik van 2 laboratoria in de database. Tot en met 2009 zijn de geurconcentratiemetingen in de stalluchtmonsters door het ASG-geurlaboratorium uitgevoerd dat in dat jaar zijn werkzaamheden beëindigde. Vanaf eind 2009 zijn deze analyses uitgevoerd door het geurlaboratorium van Buro Blauw. Het gecombineerde tijdvak-effect voor en vanaf 2001 (aangeduid als F-2001) heeft betrekking op een verandering in de voersamenstelling als gevolg van het verbod op diermeel per 1 januari 2001 in de pluimveehouderij en de omschakeling in het ASG-geurlaboratorium naar een ander model olfactometer die eveneens in 2001 plaatsvond.

Tabel 1 Overzicht van aantal meetlocaties en meetdagen voor een aantal factoren

\begin{tabular}{|c|c|c|c|}
\hline Kenmerk & & Aantal stallen & Aantal metingen \\
\hline \multirow[t]{4}{*}{ Stalsysteem } & Grondhuisvesting zonder emissie-arm systeem & 12 & 80 \\
\hline & voor ammoniak & & \\
\hline & Grondhuisvesting met emissie-arm systeem voor & 16 & 117 \\
\hline & ammoniak & & \\
\hline \multirow[t]{2}{*}{ Tijdvak: F-geurlab } & ASG & 23 & 148 \\
\hline & Buro Blauw & $9 *$ & 49 \\
\hline \multirow[t]{2}{*}{ Tijdvak: F-2001 } & Tot 2001 & 4 & 40 \\
\hline & Vanaf 2001 & 24 & 157 \\
\hline Aanwezigheid & Staltemperatuur & 28 & 171 \\
\hline Klimaat- en & Buitentemperatuur & 24 & 159 \\
\hline productiegegevens & Ventilatiedebiet & 28 & 197 \\
\hline
\end{tabular}

* bij 5 stallen zijn zowel metingen door Buro Blauw als door ASG uitgevoerd

\subsection{Statistische analyse en berekeningen}

Voor de actualisatie van de geuremissiefactor zijn statistische analyses uitgevoerd met twee doeleinden. Het eerste doel was zo exact mogelijk een representatieve geuremissiefactor te schatten uit de dataset die past in de huidige werkwijze van de Rgv, namelijk het berekenen van geurverspreiding op basis van de over de productieronde gemiddelde bronsterkte (geometrisch gemiddelde). Omdat de beschikbare meetdata in de database niet gelijkmatig over de rondedagen zijn verdeeld kan de geuremissiefactor niet rechtstreeks uit het gemiddelde van de database worden berekend. Wel kan de geuremissiefactor berekend worden door de variatie in geuremissie als functie van dagnummer in de ronde zo goed mogelijk te correleren aan een statistisch model en hieruit voor elke dag in de ronde de geuremissie volgens het statistisch model vast te stellen. Vervolgens kan de geuremissiefactor als geometrisch gemiddelde van de aldus geschatte dagemissies worden berekend. Ook hier wordt dit geometrische gemiddelde berekend door het gemiddelde van de natuurlijke 
logaritmes van de gemodelleerde dagemissies in een ronde uit te drukken op normale schaal via de exponentiële functie.

Het tweede doel was om de tijdspatronen in geuremissie van vleeskuikenstallen en de toevalsvariatie rond deze patronen te modelleren op basis van beschikbare omgevingsfactoren zodat deze als invoer voor verspreidingsberekeningen kan worden gebruikt. Met deze informatie wordt het mogelijk de effecten van rondegebonden patronen in emissies van vleeskuikenstallen op de geurbelasting in de omgeving door verspreidingsmodellering in te schatten. In de huidige berekeningswijze binnen VStacks worden de effecten van deze patronen door het gebruik van een constante geuremissiefactor niet meebeschouwd.

Om de data statistisch te analyseren is gebruik gemaakt van de zogenoemde REML (REsidual Maximum Likelihood) module van het statistisch pakket Genstat 17.1 (Genstat, 2016). REML gebruikt een zogenoemd gemengd lineair model. Dit type model bevat factoren met ingestelde waarden ('fixed factors'), variantiecomponenten van factoren met niet ingestelde afwijkingen ('random factors') en covariabelen.

Het volgende basis-model is gebruikt voor de analyse:

$$
Y_{i j}=C+F s t a l+b g \cdot G j+\sigma^{2}\left(L_{i}\right)+\sigma^{2}\left(L_{i} \cdot S\right)+\sigma^{2}\left(R_{i j}\right)
$$

Yij = responsvariabele, de waargenomen geuremissie op locatie i tijdens dagmeting $\mathrm{j}$, uitgedrukt op logaritmische schaal, In ( $\mathrm{OU}_{\mathrm{E}} / \mathrm{s}$ per geplaatst dier)

$\mathrm{C}=$ constante die de geuremissie op een bedrijfslocatie met gemiddeld bedrijfsmanagement vertegenwoordigt, bij het gemiddelde niveau van covariabele $G$, uitgedrukt in eenheden van $Y$

F-stal = effect van de factor ammoniakemissie-arm stalsysteem (fixed factor), waarbij onderscheid is gemaakt naar 2 niveaus: grondhuisvesting zonder emissie-arme inrichting, en overige emissie-arme stalsystemen)

$\mathrm{b}_{\mathrm{g}} \quad=$ regressiecoëfficiënt van covariabele $\mathrm{G}$, uitgedrukt als toename in $\mathrm{Y}$ per eenheid van de covariabele

$\mathrm{G}=$ covariabele dagnummer $\mathrm{j}$ in de productieronde

$\sigma^{2}\left(L_{i}\right)=$ variantiecomponent behorende bij de verdeling van stallocaties $\mathrm{i}$ (random factor), in eenheden van $Y$

$\sigma^{2}\left(L_{i} . S\right)=$ variantiecomponent behorende bij een verdeling die de interactie tussen stallocaties $i(L)$ en stalsysteem (F) beschrijft (random factor), in eenheden van Y. De term beschrijft de aanvullende tussen-locaties variatie als gevolg van interactie tussen bedrijfsmanagement en stalsysteem

$\sigma^{2}\left(R_{i j}\right)=$ variantiecomponent die de restterm beschrijft voor de waarnemingen op locatie i tijdens meetdag $\mathrm{j}$, in eenheden van $\mathrm{Y}$

De responsvariabele is op logaritmische schaal gemodelleerd omdat de residuele spreiding op normale schaal een proportioneel karakter vertoonde. Dit is een bekende eigenschap die in eerdere geuremissie-analyse ook naar voren trad (Ogink en Lens, 2001). Voor elke afzonderlijke modelcomponent is getoetst of deze significant bijdroeg aan het beschrijven van de variatie in de dataset (Wald-statistics en F-toets) door de individuele component van het volledige model te verwijderen. Op basis van deze toetsen is het basismodel is bijgesteld.

Aan het overgebleven basismodel is vervolgens een aantal factoren en covariabelen toegevoegd om te onderzoeken of zij de variatie in geuremissie met een hogere correlatie konden beschrijven. De volgende factoren (fixed) zijn hiervoor onderzocht:

- F-geurlab: factor met onderscheid naar 2 laboratoriumniveaus, analyses uitgevoerd door het ASGlaboratorium (alle data tot en met 2009) en door het Buro Blauw-laboratorium vanaf 2010

- F-2001: factor met 2 tijdvakniveaus, geuremissie tot 2001 en vanaf 2001: in het tijdvak tot 2001 bevatte het voer standaard beendermeel, daarna niet meer; deze verandering valt samen met de inzet van een nieuwe olfactometer in het ASG-laboratorium na 2001. 
De effecten van de volgende covariabelen zijn eveneens onderzocht:

- Ventilatiedebiet (V, $\mathrm{m}^{3} /$ uur per dier, in de analyse uitgedrukt op In-niveau en op deze schaal in de tekst aangegeven als In-debiet)

- Staltemperatuur (T-binnen)

- Buitentemperatuur (T-buiten)

Ten behoeve van de modellering van geuremissie-patronen en het vaststellen van over een standaard productieronde (geometrisch) gemiddelde emissiewaarde is eveneens de modellering van het ventilatiedebiet als functie van dagnummer en omgevingsvariabelen onderzocht.

Hiervoor werd het volgende regressiemodel gebruikt:

$$
Y_{j}=C+b 1 \cdot G j+b 2 \cdot \text { Tbuitenj }
$$

Yj = responsvariabele, ventilatiedebiet op dagnummer $\mathrm{j}$, uitgedrukt op logaritmische schaal, $\ln \left(\mathrm{m}^{3} /\right.$ uur per geplaatst dier)

C = constante uitgedrukt op het gemiddelde niveau van covariabele $\mathrm{G}$ en Tbuiten, uitgedrukt in eenheden van $Y$

b1 = regressiecoëfficiënt van covariabele $G$, uitgedrukt als toename in $Y$ per eenheid van de covariabele

$\mathrm{G}=$ covariabele dagnummer $\mathrm{j}$ in de productieronde

b2 = regressiecoëfficiënt van covariabele Tbuiten, uitgedrukt als toename in $Y$ per eenheid van de covariabele

Tbuiten = covariabele buitentemperatuur (C), tijdens geurmeting, op dag $\mathrm{j}$. 


\section{Resultaten}

\subsection{Statistische analyse variabiliteit geuremissie}

In figuur 1 zijn alle gemeten geuremissie-data (In-schaal) geplot tegen dagnummer in de productieronde. De plot laat een lineair verband zien tussen de In-geuremissie en dagnummer in de ronde met een ruime spreiding rond de gemiddelde In-geuremissie per dag.

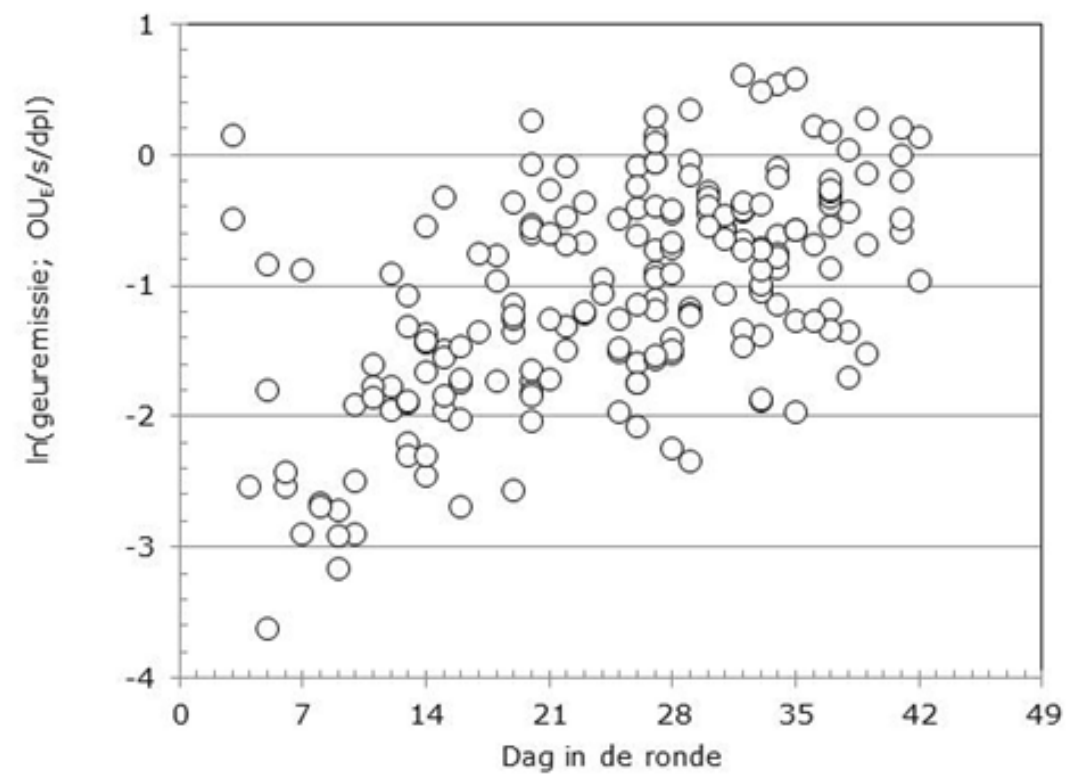

Figuur 1 De gemeten geuremissie, uitgedrukt als $\ln \left(O U_{E} / s\right.$ per geplaatst dier), tegen het dagnummer in de productieronde; alle waarnemingen uit de database.

De spreiding in geuremissie is allereerst onderzocht met het basismodel met daarin dagnummer in de productieronde $\mathrm{G}$ als covariabele en de factor F-stal (grondhuisvesting versus emissie-arme huisvesting). Uit toetsing van de bijdrage van de modelcomponenten aan beschrijvend vermogen van het basismodel blijkt dat er geen aanleiding is een effect van F-stal op de geuremissie op te nemen $(P>0.10)$, maar wel van de covariabele $G(P<0.001)$. Het effect van de covariabele $G$ wordt uitgedrukt via regressiecoëfficiënt $b_{G}=0.0484$ (s.e. $=0.0048$ ), en een regressieconstante $C$ van -1.038 (s.e. 0.0765 ) bij een gemiddelde waarde van $\mathrm{G}$ van 24.9 dagen in de dataset, en een residuele variantie van 0.379 (s.e. 0.0409) die als residuele standaarddeviatie (RSD) uitgedrukt 0.616 bedraagt.

Vervolgens zijn de effecten van andere factoren en covariabelen onderzocht met het basismodel zonder F-stal. Bij de factoren blijkt dat het tijdsvak-effect, uitgedrukt via factor F-2001, een zwak significant effect op het beschrijvend vermogen van het uitgebreide basismodel laat zien $(P<0.076)$ en geen verbetering van beschrijvend vermogen door de factor geurlaboratorium ( $F$-geurlab) $(P>0.10)$. Bij de covariabelen leidt alleen de toevoeging van ventilatieniveau $\ln (\mathrm{V})$ tot een beter beschrijvend vermogen $(P<0.001)$, naast de covariabele $G(P<0.003)$ van het basismodel, terwijl opname van $T$ binnen en $T$-buiten niet tot een verbetering leidt $(P>0.10)$. 
Dit levert uiteindelijk het volgende best beschrijvende model voor de $\ln$ (geuremissie) op:

$$
\mathrm{Y}_{\mathrm{ij}}=\mathrm{C}+\mathrm{F}-2001+\left[\mathrm{b}_{\mathrm{G}} \times\left(\mathrm{G}-\mathrm{G}_{\mathrm{gem}}\right)\right]+\left[\mathrm{b}_{\operatorname{lnv}} \times\left(\operatorname{lnV}-\ln \mathrm{V}_{\mathrm{gem}}\right)\right]+\sigma^{2}\left(L_{i}\right)+\sigma^{2}\left(L_{i} \cdot S\right)+\sigma^{2}\left(R_{i j}\right)
$$

met:

C+ F-2001 = - 1.355 en -0.924, resp. vóór 2001 en vanaf 2001: (verschil 0.43 met s.e. $=0.228$ )

$\mathrm{b}_{\mathrm{G}}: \quad=0.0144$ (s.e. $\left.=0.0066\right)$

$\mathrm{G}_{\mathrm{gem}} \quad=24.9$, gemiddeld niveau dagnummer in de meetgegevens

$\mathrm{b}_{\operatorname{lnv}} \quad=0.4605$ (s.e. $\left.=0.0677\right)$

$\mathrm{InV}_{\text {gem }} \quad=0.4001$ gemiddeld niveau $\ln (\mathrm{V})$ in de meetgegevens

$\sigma^{2}\left(L_{i}\right)+\sigma^{2}\left(L_{i} \cdot S\right)=0.1021$ (s.e. $\left.=0.0457\right)$, uitgedrukt als s.d.: 0.32

$\sigma^{2}\left(R_{i j}\right) \quad=0.298$ (s.e. $=0.0319$ ), uitgedrukt als RSD: 0.55

Ten opzichte van het basismodel is het beschrijvend vermogen van dit model toegenomen, zoals uitgedrukt in de spreiding van de restterm van de modellen (RSD). Deze spreiding (op In-schaal) daalt van 0.616 naar 0.55 .

\subsection{Berekening geuremissiefactor}

De meest nauwkeurige schatting voor het geometrisch gemiddelde van een productieronde kan verkregen worden door de over een productieronde van 42 dagen gemiddelde In-geuremissie te berekenen met het best beschrijvende statistische model voor emissie. Zoals uit de analyse blijkt is dit een lineair model met de covariabelen dagnummer in de ronde $(G)$ en $\ln$-debiet $(\operatorname{In}(V))$, en de factor F-2001. Door voor elk dagnummer de geschatte In-geuremissie te berekenen kan hieruit de geuremissie als het overall gemiddelde over 42 dagen worden vastgesteld. Het effect van factor F2001 wordt daarin meegenomen door het niveau van de geuremissie in het tijdvak vanaf 2001 toe te passen. Omdat de beide covariabelen in het statistische model een lineair verband met In-geuremissie hebben kan de gemiddelde In-geuremissie over een ronde van 42 dagen berekend worden door de Ingeuremissie bij het gemiddelde dagnummer over 42 dagen (21.5) en het bijbehorende gemiddelde $\mathrm{In}$ debiet uit te rekenen. Dit geeft hetzelfde resultaat als de In-geuremissies voor de dagnummer $1 \mathrm{t} / \mathrm{m}$ 42 afzonderlijk te berekenen en vervolgens te middelen over de 42 waarnemingen.

Om de voorgestelde berekening uit te voeren dient dan wel eerst de waarde van het gemiddelde Indebiet bij het gemiddelde dagnummer 21.5 te worden berekend. De in dataset waargenomen gemiddelde waarden van de covariabelen $\mathrm{G}$ en $\ln (\mathrm{V})$ zijn hiervoor niet geschikt, omdat de data niet evenredig over de ronde zijn verdeeld. Het tweede deel van de ronde bevat een groter aantal waarnemingen. Het gemiddelde van de dagnummers in de dataset bedraagt 24.9, en is daarmee hoger dan het gemiddelde dagnummer van 21.5 dagen in een ronde van 42 dagen.

Om het In-debiet op dagnummer 21.5 te kunnen vaststellen is de relatie tussen beide variabelen onderzocht. In Figuur 2 is ventilatiedebiet op In-schaal uitgezet tegen het dagnummer. De figuur laat tussen beide een duidelijk lineair verband zien. Nadere statistische analyse van deze relatie geeft aan dat het ventilatiedebiet het best beschreven kan worden op In-schaal met een lineair regressiemodel, waarin opgenomen de covariabelen G (dagnummer in de ronde) en T-buiten (buitentemperatuur). Dit levert de volgende geschatte parameters:

C $\quad=0.4565$ (s.e. $=0.0429$ ), bij $\mathrm{G}_{\mathrm{gem}}=24.9$ en T-buiten gem $^{=} 13.1$

b1: $\quad=0.06359$ (s.e. 0.004388 ), regressiecoëfficiënt dagnummer

b2: $\quad=0.05308$ (s.e. $=0.006538$ ) regressiecoëfficiënt buitentemperatuur 


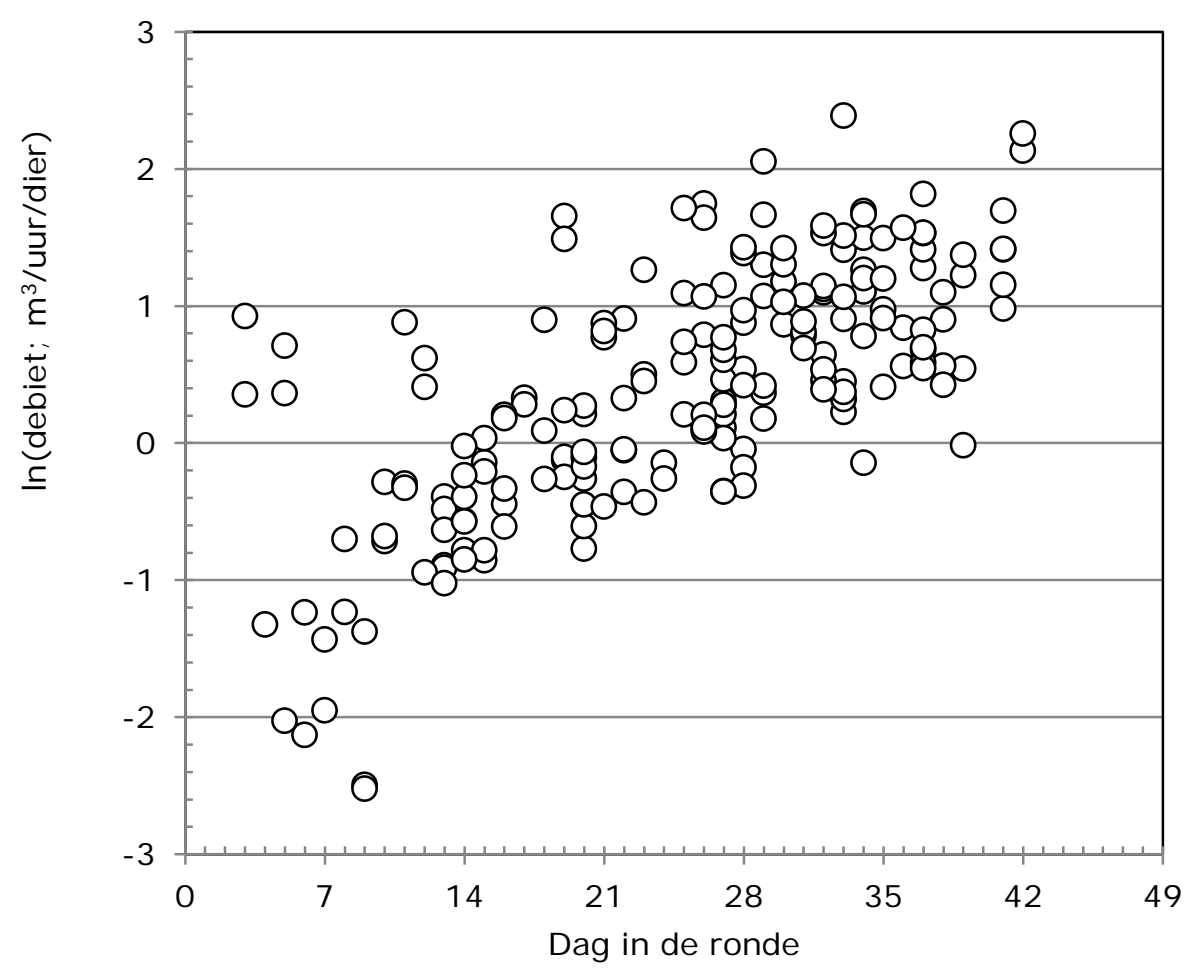

Figuur 2 Het gemeten ventilatiedebiet, uitgedrukt als $\ln \left(\mathrm{m}^{3} /\right.$ uur per geplaatst dier), tegen het dagnummer in de productieronde; alle waarnemingen uit de database.

Door het lineaire karakter van dit model kan het gemiddelde In-debiet in een ronde worden berekend uit het gemiddelde dagnummer in de ronde (21.5) en de gemiddelde T-buiten. In de dataset bedraagt T-buiten gemiddeld $13.1{ }^{\circ} \mathrm{C}$. De door het KNMI in De Bilt vastgelegde tienjaargemiddelde $(2004 \mathrm{t} / \mathrm{m}$ 2013) ligt echter met $10.5{ }^{\circ} \mathrm{C}$ wat lager dan de T-buiten in de database (KNMI, 2016). Voor de berekening van een geuremissiefactor is het tienjaargemiddelde meer representatief dan het niveau in de database. Invulling van dagnummer 21.5 en T-buiten 10.5 levert een gemiddelde In-debiet van 0.1023 . Op normale schaal uitgedrukt komt dit overeen met een debiet van $1.11 \mathrm{~m}^{3} /$ uur per geplaatst dier. In de database lag het gemiddelde niveau bij 24.9 dagen en T-buiten wat hoger met 0.4001 , gelijk aan $1.49 \mathrm{~m}^{3} /$ uur per geplaatst dier op normale schaal.

Met de verkregen representatieve gemiddelde waarden voor covariabele $G(=21.5)$ en covariabele $\ln (\mathrm{V})(=0.1023)$ kan de gemiddelde In-geuremissie uit het statistisch model voor geuremissie worden berekend. In het tijdvak voor 2001 bedraagt deze op In-schaal -1.5411, wat op normale schaal overeenkomt met $0.214 \mathrm{OU}_{\mathrm{E}} / \mathrm{s}$ per geplaatst dier. Voor het tijdvak vanaf 2001 bedraagt deze op Inschaal -1.1101, op normale schaal gelijk aan $0.330 \mathrm{OU}_{\mathrm{E}} / \mathrm{s}$ per geplaatst dier.

\subsection{Geuremissiecurve voor verspreidingsberekeningen}

De in hoofdstuk 3.1 uitgewerkte modellen voor de geuremissie en ventilatiedebiet kunnen gebruikt worden om geuremissiepatronen van een bedrijf over de seizoenen te plotten. Het ventilatiedebiet kan verklaard worden door dagnummer in de ronde en de buitentemperatuur. De invloed van buitentemperatuur op het debietniveau kan hier mee over de seizoenen heen worden doorgerekend. Met het aldus berekende ventilatiedebiet kan het verloop van de geuremissie gedurende een jaar worden weergegeven. In Figuur 3 is het verloop opgenomen van de geuremissie gedurende een gemiddeld meteorologisch jaar (KNMI, 2016), met onderscheid naar het emissieniveau voor en vanaf 2001. De figuur laat zien dat de seizoenvariatie ondergeschikt is aan de dynamiek binnen een productieronde. 


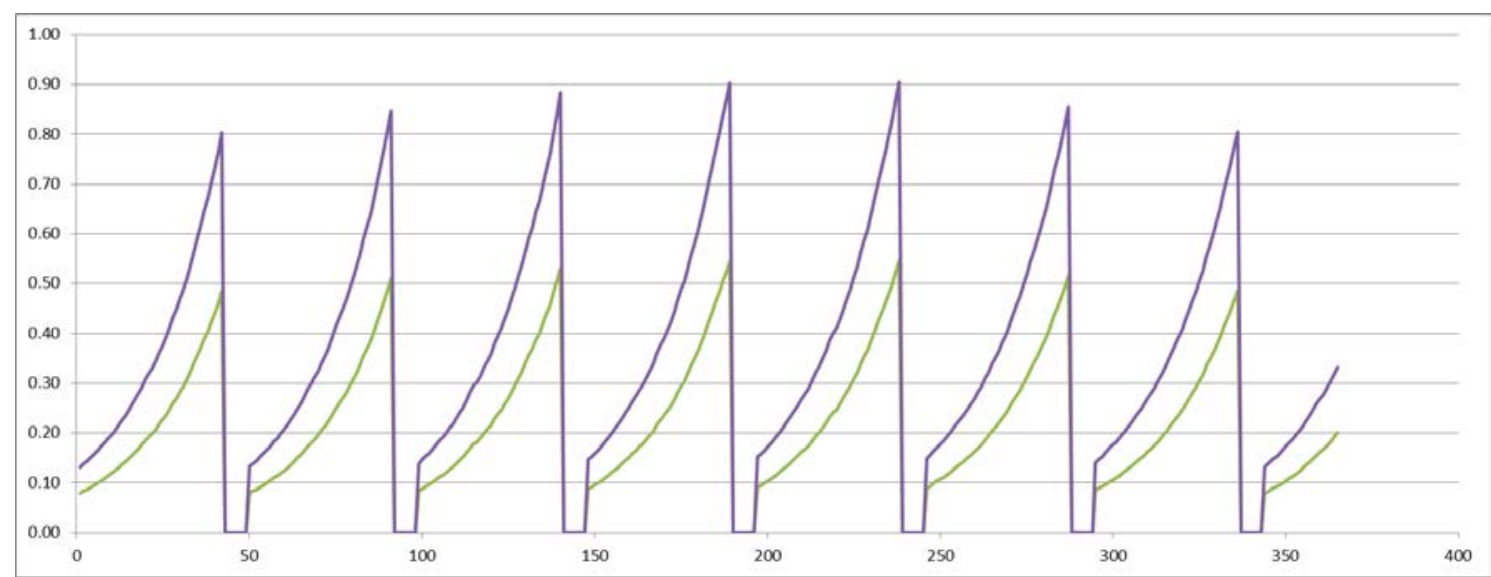

Figuur 3 Verloop van de geuremissie $\left(\mathrm{OU}_{E} / \mathrm{s}\right.$ per geplaatst dier) als functie van dagnummer in een meteorologisch gemiddeld jaar met productierondes van 42 dagen en 7 dagen leegstand tussen de rondes. Zowel de geschatte niveaus voor het tijdvak tot 2001 (groen) als vanaf 2001 (paars) zijn weergegeven.

Het weergegeven verloop geeft de verwachtingswaarde van de geuremissie en negeert het optreden van toevalsvariatie die van dag tot dag optreedt. Uit de statistische analyse blijkt dat de hoeveelheid niet verklaarde restvariantie een aanzienlijk niveau heeft (RSD $=0.55)$. Uitgedrukt op normale schaal betekent dit dat verhoging van het niveau met 1 standaarddeviatie neerkomt op een toename van $73 \%$ van de verwachtingswaarde en een soortgelijke verlaging met een afname van $42 \%$ van de verwachtingswaarde. Wel mag verwacht worden dat deze toevalsvariatie van dag tot dag enigszins samenhangt (autocorrelatie), zoals veelvuldig waargenomen in emissieprocessen, en daarmee wat wordt getemperd. Omdat in de dataset niet beschikt kon worden over opeenvolgende dagwaarnemingen op hetzelfde bedrijf is niet exact duidelijk hoe sterk deze samenhang in de tijd is.

Een andere toevalscomponent die niet in Figuur 3 is opgenomen zijn de verschillen tussen bedrijfslocaties. In de variantieanalyse is hiervoor op In-schaal een standaarddeviatie van 0.32 ingeschat. Deze systematische spreiding tussen bedrijven komt uitgedrukt op normale schaal neer op een toename/afname van de verwachtingswaarde met $+38 /-27 \%$ per eenheid standaarddeviatie. 


\section{$4 \quad$ Discussie en conclusies}

De statistische analyse van de variatie in geuremissie levert geen aanwijzing dat emissiearme stalsystemen (zonder nageschakelde technieken) ontwikkeld voor een lage ammoniakemissie, een lagere geuremissie hebben dan conventionele huisvesting van vleeskuikens. Deze bevinding komt overeen met een eerdere analyse in een vergelijkende studie gebaseerd op de meetgegevens van vleeskuikens tot 2001 (Mol en Ogink, 2002). De huidige analyse bevat veel meer ammoniakarme stallen en versterkt de onderbouwing van deze bevinding. Lagere ammoniakemissie in vleeskuikenstallen wordt in het algemeen gerealiseerd door verbeterde luchtcirculatie in de stal met een zodanig effect op de strooiselconditie dat hierdoor ammoniakvorming (uit urinezuur) en vervluchtiging wordt geremd. In een recente studie van Aarnink et al. (2016) naar het mechanisme van ammoniakemissie en de bepalende factoren in het strooisel van vleeskuikens wordt geconcludeerd dat met name strooisel-pH, rulheid en luchtsnelheid over het strooisel van belang zijn. Een belangrijk deel van de variatie in ammoniakemissie kan echter (nog) niet verklaard worden door strooiselparameters. Met betrekking tot geuremissie is fundamenteel onderzoek naar de hierbij betrokken processen in strooisel van pluimveestallen, en vleeskuikenstallen in het bijzonder, voor zover bekend nooit uitgevoerd. Ammoniak is in de stal zelf vaak wel waarneembaar met concentraties net boven de waarde voor geurwaarneming (geurdrempelwaarde ligt rond 2.5 ppm; Smeets et al, 2007). Uit het ontbreken van effect van ammoniakreductie op geuremissie mag er vanuit gegaan worden dat ammoniak in de geurwaarneming een zeer beperkte rol gaat. Geurprofielen in stallucht zijn in het algemeen opgebouwd uit tientallen componenten die bijdragen aan de geurbeleving, waarbij velen in concentraties voorkomen die relatief veel hoger boven hun geurdrempelwaarde uitkomen dan bij ammoniak. Voor het begin van enig begrip in de vorming van geur is kennis van de samenstelling van het geurprofiel via chemisch-analytische methoden noodzakelijk. Op dit gebied zijn vooral in varkenstallen afgelopen jaren vorderingen gemaakt (zie o.a. Hansen et al., 2016), maar ontbreekt onderzoek in pluimveestallen.

Uit de data-analyse blijkt dat er geen aanwijzingen zijn dat de uitvoering van de geurconcentratiemetingen beïnvloed is door verschillen tussen de beide geurlaboratoria die in de database voorkomen. In eerder vergelijkend onderzoek tussen geurlaboratoria (Jonassen et al., 2012) met analyses van stallucht bleken er zeer grote verschillen tussen laboratoria te kunnen optreden, binnen het gebruik van dezelfde Europese standaard (EN13725). Bij de overgang in 2009 van geurmetingen binnen het ASG-stalonderzoek naar een ander geurlaboratorium heeft vergelijkend onderzoek plaatsgevonden tussen het oude en nieuw laboratorium waarbij gebruik werd gemaakt van hetzelfde geurpanel. In een serie van acht praktijkmonsters die de hele bandbreedte van geurconcentraties in voorkomende stallucht bestreek $\left(60\right.$ tot $6000 \mathrm{OU}_{\mathrm{E}} / \mathrm{m}^{3}$ ) bleken er geen aanwijzingen te zijn voor systematische verschillen tussen beide labs (zie bijlage 2). De gemiddelde verhouding van geurconcentraties (1.05) was kleiner dan de standaardafwijking van de verhoudingen (1.2). De resultaten uit deze vergelijkende meetserie bevestigen het beeld uit de statistische analyse. Geconcludeerd kan worden dat er geen aanwijzingen zijn dat de inzet van meerdere geurlabs de consistentie van het meetniveau van geurconcentratie heeft beïnvloed.

De geuremissie gedurende de productieronde is sterk gecorreleerd met het dagnummer en het ventilatiedebiet. Het dagnummer is een uitdrukking van de toename in diermassa, van ca 0.05 naar 2 $\mathrm{kg}$ levend gewicht, en de daarmee gepaard gaande toename in voeropname en mestuitscheiding. Van dag tot dag stijgt de geuremissie met 1,5\% (afgeleid van parameter $b_{G}$ in het best beschrijvende statistische model, berekend als $\mathrm{e}^{0.0144}$ ). Met toenemend gewicht stijgt ook de warmteproductie in de stal en zal de ventilatiebehoefte toenemen. Het dagnummer in de ronde en het ventilatieniveau zijn daarom positief met elkaar gecorreleerd. In het model dat de toename van ventilatieniveau beschrijft neemt de ventilatie met gemiddeld $6,5 \%$ per dag toe (regressiecoëfficiënt b1, $e^{0.0636}$ ). Opname van ventilatieniveau naast dagnummer in het statistisch model voor geuremissie draagt bij aan een betere beschrijving van de geuremissie, wat op zich niet verwonderlijk is omdat de geuremissie berekend is als het product van ventilatiedebiet en gemeten geurconcentratie. Omdat dagnummer en 
ventilatiedebiet sterk gecorreleerd zijn dienen de geschatte regressiecoëfficiënten in het model voor geuremissie altijd in samenhang met elkaar te worden beschouwd.

De omvang van de geuremissie uit dierverblijven wordt in de regelgeving uitgedrukt als geuremissiefactor. In het meetprotocol voor het bepalen van een geuremissie-factor wordt in de bemonsteringsstrategie voor vleeskuikenstallen de nadruk gelegd op het derde deel van de groeicurve. Per stal vindt er 1 meting in het eerste ronde-deel (week 1+2) plaats, 2 in het tweede ronde-deel (week $3+4$ ), en 3 in het derde ronde-deel (week 5+6). De geuremissiefactor wordt vervolgens berekend door eerst de gemiddelde waarden binnen elk ronde-deel te berekenen, en daarna het overall gemiddelde te nemen van de drie ronde-deel gemiddelden in de productieronde. Op deze wijze wordt de informatie uit de drie opeenvolgende ronde-delen met een gelijk gewicht in de berekening opgenomen. Voor geur wordt daarbij gerekend met het geometrisch gemiddelde, berekend uit het gemiddelde van de geuremissies op logschaal (met het log-gemiddelde teruggerekend naar normale schaal). De gedachte hierachter is dat de geuremissie in de tijd lognormaal is verdeeld en dat het gemiddelde van deze verdeling (de mediaan op normale schaal) het beste startpunt is voor verspreidings-berekeningen om percentielwaarden in de omgeving vast te stellen.

Een alternatief voor de hierboven beschreven tijdvakmethode is het modelleren van geuremissiecurve als functie van dagnummer in de productieronde en vervolgens de geuremissiefactor te berekenen als het gemiddelde van de gemodelleerde dagwaarden over de ronde. Dit is t.o.v. de benaderende rondedeel methode theoretisch een betere benadering, mits een goede beschrijving van de emissiecurve mogelijk is. Normaliter is de informatie uit de bemonstering van één stalsysteem met minimaal 24 waarnemingen te beperkt om dit goed vorm te geven. In de meta-analyse in deze studie kon echter over een veel groter aantal metingen, afkomstig van 28 vleeskuikenbedrijven, worden beschikt waardoor modellering van de geuremissiecurve een veel bredere basis heeft. De beschrijving van de geuremissiecurve met statistische modellen heeft bovendien als voordeel dat effecten van omgevingsfactoren op de geuremissie kunnen worden gekwantificeerd. Dit maakt het mogelijk de geuremissiefactor te berekenen voor zo representatief mogelijk gekozen gemiddelde niveaus van beschrijvende variabelen. Het is namelijk goed mogelijk dat ook in een grote database het niveau van belangrijke verklarende variabelen hier iets van afwijken. De in hoofdstuk 3.2 berekende geuremissiefactor is gebaseerd op het best beschrijvende statistische model met daarin een berekend gemiddeld ventilatiedebiet dat is afgestemd op een zo representatief mogelijk gemiddelde buitentemperatuur. Door deze aanpak is het tevens mogelijk het karakteristieke 'zaagtand'verloop van de geuremissie, als gevolg van het all-in all-out systeem op vleeskuikenbedrijven, over de seizoenen heen te kwantificeren. Het opnemen van deze informatie in verspreidingsberekeningen geeft een meer realistisch beeld bij de inschatting van de 98-percentielwaarden in de geurbelaste omgeving dan berekeningen gebaseerd op een constante bronsterkte. In een scenario-studie met vleeskuikenstallen van Verhees en Erbrink (2015) is eerder aangetoond dat het opnemen van rondegebonden variatie in geuremissie effect heeft op de berekende 98-percentielwaarden.

In de berekening van de geuremissiefactor (hoofdstuk 3.2) dienen keuzes gemaakt ten aanzien van het tijdvak in de database waaruit de geuremissiefactor wordt berekend en het gemiddelde niveau van het ventilatiedebiet dat gebruikt wordt bij de berekening van de geuremissiefactor. In Tabel 2 zijn de effecten van deze keuzes op de te berekenen geuremissiefactor weergegeven.

Tabel 2 Geuremissiefactor ( $\mathrm{OU}_{E} / \mathrm{s}$ per geplaatst dier) berekend op basis van de data voor 2001, vanaf 2001 en op basis van alle data, onderscheiden naar wel of geen correctie van het ventilatiedebiet naar gemiddelde buitentemperatuur van $10.5 \mathrm{C}$

\begin{tabular}{llll} 
& Data $t / \mathrm{m} \mathrm{2001}$ & Data vanaf 2001 & Alle data \\
zonder debietcorrectie & 0.23 & 0.35 & 0.30 \\
\hline met debietcorrectie & 0.21 & 0.33 & 0.28 \\
\hline
\end{tabular}

Het toepassen van debietcorrectie op basis van een meer representatieve buitentemperatuur heeft een beperkte invloed op de berekende geuremissiefactor (zie 3.2). Ondanks de beperkte invloed is een zo representatief mogelijke inschatting van het effect van debietniveau niettemin wel gewenst voor het vaststellen van een nieuwe geuremissiefactor. 
Op basis van kennis van tegelijkertijd optredende veranderingen in 2001 die mogelijk effect kunnen hebben op de geuremissie is besloten een onderscheidende tijdvakfactor in de analyse op te nemen. Met deze tijdvakfactor kon het verschil in geuremissieniveau tussen data uit onderzoek tot 2001 en onderzoek vanaf 2001 worden geanalyseerd. Het gaat hier om wijzigingen in voersamenstelling (het verbod op dierlijk eiwit in 2001) en apparatuur bij geurmetingen (wijziging in het type olfactometer in ASG-laboratorium waardoor panelleden gelijktijdig in plaats van na elkaar de verdunningen van aangeboden luchtmonsters beoordelen). Hoewel het effect van wijziging in olfactometer-uitvoering waarschijnlijk gering is t.o.v. het mogelijke effect van een wijziging in voersamenstelling kunnen de afzonderlijke effecten niet uit elkaar worden gehaald. Uit de analyse komt een groot verschil tussen beide tijdvakken naar voren met een gemiddeld meer dan de helft hogere geuremissie vanaf 2001 (op In-schaal een verschil van 0.43). De schatting voor dit verschil bevat wel een aanzienlijke spreiding $(s d=0.23$ ) en de $p$-waarde horende bij de toets van de nulhypothese (geen effect van tijdvak) ligt met $p<0.07$ tussen een matig en sterk significantie-niveau. Het advies is niettemin, gezien de technische plausibiliteit van het effect en het gegeven dat de meer recentere reeksen vanaf 2001 zijn verkregen van bedrijven die qua management en uitvoering dichter bij de huidige vleeskuikenbedrijven staan, de geactualiseerde geuremissiefactor te baseren op het geschatte niveau van dit tweede tijdvak.

Samenvattend wordt geconcludeerd dat de huidige geuremissiefactor factor in de Rgv $\left(0.24\right.$ OU $/ \mathrm{s}_{\mathrm{ser}}$ geplaatst dier) dient te worden geactualiseerd naar een hoger niveau. Geadviseerd wordt deze te baseren op het best beschrijvende statistische model, het niveau af te stemmen op het tijdvak vanaf 2001 en de voorgestelde correctie naar een representatief ventilatiedebiet. De geactualiseerde geuremissiefactor bedraagt dan $0.33 \mathrm{OU}_{E} / \mathrm{s}$ per geplaatst dier. Geadviseerd wordt bij de berekeningen met het $\mathrm{V}$-Stacks model rekening te houden met het zaagtandpatroon in geuremissie. 


\section{Literatuur}

Aarnink, A.J.A, Harn, J. van, Blanken, K., en N.W.M. Ogink. 2016. Ontwikkeling van een rekentool om de ammoniakemissie uit vleeskuikenstallen te kunnen voorspellen. Livestock Research Rapport (in voorbereiding), Wageningen UR Livestock Research, Wageningen.

Geelen, L., Boers, D., Brunekreef, B. en I. Wouters. 2015. Geurhinder van veehouderij nader onderzocht: meer hinder dan Handreiking Wgv doet vermoeden? Actualisatie blootstellingresponsrelatie tussen gemodelleerde cumulatieve geurbelasting en geurhinder in Noord-Brabant en Limburg-Noord. Bureau Gezondheid, Milieu \& Veiligheid van de GGD'en Brabant/Zeeland en Institute for Risk Assessment Sciences, Universiteit Utrecht.

Genstat, 2016. GenStat Reference Manual, Release 17.1. VSN-International, Ltd, Hemel Hempstead, Verenigd Koninkrijk.

Hansen, M.J., Jonassen, K.E.N., Løkke, M.M., Adamsen, A.P.S. \& Feilberg, A. 2016. Multivariate prediction of odor from pig production based on in-situ measurement of odorants. Atmospheric Environment, Vol. 135, pp. 50-58.

J onassen, K.E.N., Pedersen, P., Riis, A.L. \& Sørensen, K. 2012 Does the Choice of Olfactometric Laboratory Affect the Efficiency of Odour Abatement Technologies? Chemical Engineering Transactions 30, 43-48.

KNMI, 2016. Weblink: http://www.knmi.nl/nederland-nu/klimatologie. Benaderd juni 2016.

Mol, G. en N.W.M. Ogink. 2002. Geuremissies uit de veehouderij II Overzichtsrapportage 2000-2002. IMAG-rapport 2002-09, IMAG, Wageningen.

NEN-EN 13725:2003. Lucht - Bepaling van de geurconcentratie door dynamische olfactometrie, Nederlands Normalisatie-instituut, Delft.

Ogink, N.W.M. 2010. Vaststelling van geuremissiefactoren in de regeling geurhinder en veehouderij op basis van geuremissie-onderzoek. Livestock Research rapport 391, Wageningen UR Livestock Research, Wageningen.

Ogink, N.W.M. 2011. Protocol voor meting van geuremissie uit huisvestingssystemen in de veehouderij 2010. Livestock Research rapport 491, Wageningen UR Livestock Research, Wageningen.

Ogink, N.W.M. en P.N. Lens. 2001. Geuremissies uit de Veehouderij. Overzichtsrapportage van geurmetingen in de varkenshouderij, pluimveehouderij en rundveehouderij. I MAG-rapport, 200114, IMAG, Wageningen

Smeets, M.A.M., Bulsing, P.J., Rooden, S. van, Steinmann, R., Ru, J.A. de, Ogink, N.W.M., Thriel, C. van \& Dalton, P.H. 2007. Odor and irritation thresholds for ammonia: A comparison between static and dynamic olfactometry. Chemical Senses 32 (2007) 1.

Verhees, L. en Erbrink, H. 2015. Effect van meer realistische warmte emissies en variabele stofemissies op de PM10, geur en NH3 concentraties bij pluimveehouderijen. KEMA Nederland BV, Arnhem. 


\section{Bijlage 1 Overzicht metingen}

Overzicht beschikbare datasets

\begin{tabular}{|c|c|c|c|c|}
\hline $\begin{array}{l}\text { Onderzoeks- } \\
\text { programma }\end{array}$ & Stalsysteem & Locatie & Referentie & \\
\hline \multirow[t]{4}{*}{ Pythia } & Grondhuisvesting & Beekbergen & Ogink en Lens (2001) & IMAG Rapport 2001-14 \\
\hline & Grondhuisvesting & Nijega & Ogink en Lens (2001) & IMAG Rapport 2001-14 \\
\hline & $\begin{array}{l}\text { Grondhuisvesting met } \\
\text { strooiseldroging }\end{array}$ & Beekbergen & Ogink en Lens (2001) & IMAG Rapport 2001-14 \\
\hline & $\begin{array}{l}\text { Strooiselkoeling en } \\
\text { verwarming }\end{array}$ & Riel & Mol en Ogink (2001) & niet gepubliceerd \\
\hline \multirow[t]{3}{*}{ Overige } & Meeretagesysteem & Lopik & Huis in 't Veld e.a. (2005) & A\&F Rapport 367 \\
\hline & Mixluchtsysteem & Assen & Scheer e.a. (2003) & IMAG Rapport 2003-15 \\
\hline & $\begin{array}{l}\text { ScanFeeder met } \\
\text { strooiselbeluchting }\end{array}$ & Lelystad & Hol e.a. (2007) & ASG Rapport 33 \\
\hline \multirow[t]{4}{*}{ Update EFs } & Grondhuisvesting & Anna Paulowna & Mosquera e.a. (2011a) & WLR Rapport 275 \\
\hline & Grondhuisvesting & Lettele & Mosquera e.a. (2011a) & WLR Rapport 275 \\
\hline & Grondhuisvesting & Maren-Kessel & Mosquera e.a. (2011a) & WLR Rapport 275 \\
\hline & Grondhuisvesting & Weert & Mosquera e.a. (2011a) & WLR Rapport 275 \\
\hline \multirow[t]{5}{*}{ PGL } & Grondhuisvesting & Lettele & Melse e.a. (2011) & WLR Rapport 380 \\
\hline & Grondhuisvesting & Lusche & Mosquera e.a. (2011b) & WLR Rapport 295 \\
\hline & Grondhuisvesting & Uden & Mosquera e.a. (2011b) & WLR Rapport 295 \\
\hline & Grondhuisvesting & Vinkel & Mosquera e.a. (2011b) & WLR Rapport 295 \\
\hline & $\begin{array}{l}\text { Grondhuisvesting met } \\
\text { luchtconditionering }\end{array}$ & Gemert & Melse e.a. (2011) & WLR Rapport 380 \\
\hline \multirow[t]{2}{*}{ MIDS } & $\begin{array}{l}\text { Grondhuisvesting met } \\
\text { luchtconditionering }\end{array}$ & Asten Heusden & Mosquera e.a. (2012) & WLR Rapport 611 \\
\hline & $\begin{array}{l}\text { Grondhuisvesting met } \\
\text { warmtewisselaar }\end{array}$ & Langeveen & Mosquera e.a. (2013) & WLR Rapport 657 \\
\hline \multirow[t]{11}{*}{ Stofreductie } & Grondhuisvesting & Sint-Anthonis & Winkel e.a. (2011a) & WLR Rapport 392 \\
\hline & Grondhuisvesting & Lierop & Winkel e.a. (2011a) & WLR Rapport 392 \\
\hline & Grondhuisvesting & Manderveen & Van Harn e.a. (2015) & WLR Rapport 845 \\
\hline & $\begin{array}{l}\text { Grondhuisvesting met } \\
\text { gedroogde maïs }\end{array}$ & Manderveen & Van Harn e.a. (2015) & WLR Rapport 845 \\
\hline & $\begin{array}{l}\text { Grondhuisvesting met verse } \\
\text { maïs }\end{array}$ & Manderveen & Van Harn e.a. (2015) & WLR Rapport 845 \\
\hline & $\begin{array}{l}\text { Grondhuisvesting met } \\
\text { vloerverwarming en } \\
\text { vloerkoeling }\end{array}$ & Hellendoorn & Winkel e.a. (2011b) & WLR Rapport 462 \\
\hline & Mixluchtsysteem & Kessel & Winkel e.a. (2011b) & WLR Rapport 462 \\
\hline & $\begin{array}{l}\text { Grondhuisvesting met } \\
\text { vloerverwarming en } \\
\text { vloerkoeling en Ionisatie }\end{array}$ & Hellendoorn & Winkel e.a. (2011b) & WLR Rapport 462 \\
\hline & Mixluchtsysteem en Ionisatie & Kessel & Winkel e.a. (2011b) & WLR Rapport 462 \\
\hline & Grondhuisvesting en oliefilm & Sint-Anthonis & Winkel e.a. (2011a) & WLR Rapport 392 \\
\hline & Grondhuisvesting en oliefilm & Lierop & Winkel e.a. (2011a) & WLR Rapport 392 \\
\hline
\end{tabular}




\section{Bijlage 2 Vergelijkende geurmetingen}

Vergelijkende geurmetingen van identieke stalluchtmonsters uitgevoerd met het ASG- en BLAUWlaboratorium, met identieke geurpanels per stalluchtmonster

\begin{tabular}{|c|c|c|c|c|c|c|c|}
\hline \multirow[t]{2}{*}{$\mathrm{Nr}$} & \multirow[b]{2}{*}{ Analysedatum } & \multicolumn{2}{|c|}{ ASG } & \multicolumn{2}{|c|}{ Blauw } & \multicolumn{2}{|c|}{ Verschil } \\
\hline & & $\mathrm{OU}_{\mathrm{E}} / \mathrm{m}^{3}$ & $\ln \left(O U_{E} / \mathrm{m}^{3}\right)$ & $\mathrm{OU}_{\mathrm{E}} / \mathrm{m}^{3}$ & $\ln \left(\mathrm{OU}_{\mathrm{E}} / \mathrm{m}^{3}\right)$ & $\mathrm{OU}_{\mathrm{E}} / \mathrm{m}^{3}$ & $\ln \left(O U_{E} / \mathrm{m}^{3}\right)$ \\
\hline 1 & 14-10-2009 & 3590 & 8.19 & 5240 & 8.56 & -1650 & -0.38 \\
\hline 2 & 14-10-2009 & 2855 & 7.96 & 3150 & 8.06 & -295 & -0.10 \\
\hline 3 & $15-10-2009$ & 646 & 6.47 & 699 & 6.55 & -53 & -0.08 \\
\hline 4 & 15-10-2009 & 1388 & 7.24 & 1335 & 7.20 & 53 & 0.04 \\
\hline 5 & 16-10-2009 & 2094 & 7.65 & 2116 & 7.66 & -22 & -0.01 \\
\hline 6 & 16-10-2009 & 1790 & 7.49 & 1578 & 7.36 & 212 & 0.13 \\
\hline 7 & $22-10-2009$ & 60 & 4.09 & 78 & 4.36 & -18 & -0.26 \\
\hline 8 & $22-10-2009$ & 6153 & 8.72 & 4674 & 8.45 & 1479 & 0.27 \\
\hline & gemiddelde & & 7.23 & & 7.27 & & -0.05 \\
\hline & stand. Afw. & & 1.43 & & 1.36 & & 0.21 \\
\hline & geometr. gem. & $\mathrm{OU}_{\mathrm{E}} / \mathrm{m}^{3}$ & 1347 & & 1443 & & 1.05 \\
\hline
\end{tabular}




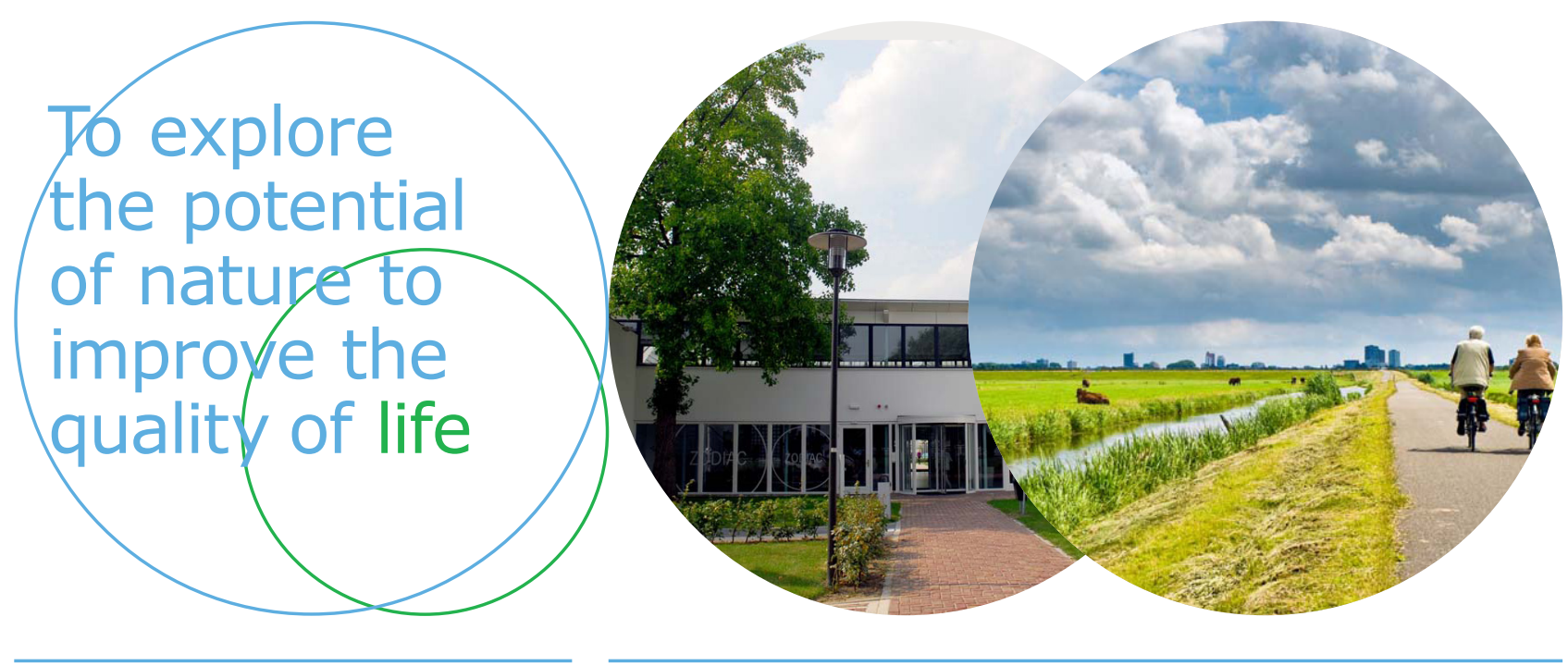

Wageningen Livestock Research Postbus 338

6700 AH Wageningen

T 0317483953

E info.livestockresearch@wur.nl www.wur.nl/livestock-research
Wageningen Livestock Research ontwikkelt kennis voor een zorgvuldige en renderende veehouderij, vertaalt deze naar praktijkgerichte oplossingen en innovaties, en zorgt voor doorstroming van deze kennis. Onze wetenschappelijke kennis op het gebied van veehouderijsystemen en van voeding, genetica, welzijn en milieu-impact van landbouwhuisdieren integreren we, samen met onze klanten, tot veehouderijconcepten voor de $21 \mathrm{e}$ eeuw.

De missie van Wageningen University \& Research is 'To explore the potential of nature to improve the quality of life'. Binnen Wageningen UR bundelen 9 gespecialiseerde onderzoeksinstituten van stichting DLO en Wageningen University hun krachten om bij te dragen aan de oplossing van belangrijke vragen in het domein van gezonde voeding en leefomgeving. Met ongeveer 30 vestigingen, 6.000 medewerkers en 10.000 studenten behoort Wageningen UR wereldwijd tot de aansprekende kennisinstellingen binnen haar domein. De integrale benadering van de vraagstukken en de samenwerking tussen verschillende disciplines vormen het hart van de unieke Wageningen aanpak. 